\title{
FURTHER ASPECTS OF SULPHUR NUTRITION OF LEGUMES
}

\author{
T. E. LuDecke
}

Scientist, Taieri Agriculture Centre, Mosgiel

\section{Introduction}

THE KEY to improving the native tussock grasslands of the South Island is to obtain good legume growth. In these areas, the main nutrient deficiencies which limit the growth of legumes are sulphur, phosphorus and molybdenum. Sulphur deficiencies are very widespread (Walker et al., 195.5; Lobb and Bennetts, 1958; McLeod, 1961).

The manner in which a rational fertilizer programme was formulated for the dryland areas of Central Otago has been described elsewhere (Ludecke, 1960, 1962a, 1962b). With the exception of a small area of very dry soils, all soils in Central Otago are extremely sulphur deficient and vary in their phosphate requirements; as the rainfall increases and the soils become more leached, the responses to phosphate in the presence of sulphur increase.

The recognition of widespread sulphur deficiencies in Central Otago and the formulation of a rational fertilizer programme has been of tremendous economic significance to the economy of Otago. On a Wanaka property on which 1,200 acres of tussock country have been improved by aerial oversowing and topdressing, the wool weight in Merino hoggets has been raised in a period of two years from $4.10 \mathrm{lb}$ per head to $7.25 \mathrm{lb}$ per head. This result has been obtained for the expenditure of $£ 3$ per acre. On this property, where the soils are extremely sulphur responsive and only slight phosphate responses are obtained, the farmer applies $1 \frac{1 / 2}{c}$ wt of sulphurized super-phosphate (400 lb mixture) and $2 \mathrm{lb}$ white clover, $2 \mathrm{lb}$ Montgomery red clover, $1 \mathrm{lb}$ alsike clover and $2 \mathrm{lb}$ cocksfoot per acre. This is the cheapest land development in New Zealand.

In trials to be reviewed in this paper, it has been found that the fineness of grinding of elemental sulphur is very important and the residual effects of gypsum are greater than those from fine or coarse sulphur. 


\section{Some General Aspects of Sulphur Nutrition of Legumes}

Sulphur may be applied to the soil in many forms including salts very soluble in water, such as potassium or ammonium sulphates, a moderately soluble salt such as gypsum, or as elemental sulphur. In the case of elemental sulphur, the sulphur must be oxidized to sulphates before it becomes available to plants. The mineralization of sulphur is carried out by micro-organisms and aspects of mineralization have been studied by a number of workers in Australia and New Zealand. Bruce-Smith ( 1962) reviewed the literature on the mineralization of elemental sulphur.

Since elemental sulphur has to be oxidized to sulphates before it becomes available to plants, it was considered by many workers that elemental sulphur would be slower acting but the residual effects would be greater than those from equivalent rates of sulphur applied as gypsum.

In recent years, superphosphate-sulphur mixtures have come on the market and are being used extensively in areas where sulphur is the major nutrient limiting legume growth. The common mixtures which are being manufactured are: (a) $200 \mathrm{lb}$ of sulphur added to a ton of superphosphate; and (b) $400 \mathrm{lb}$ of sulphur added to a ton of superphosphate.

In 1 cwt of the $400 \mathrm{lb}$ mixture of sulphurized superphosphate compared with 1 cwt of ordinary superphosphate, the phosphate content is reduced by only a sixth and the sulphur content increased by $2 \frac{1}{2}$ times.

It was recommended by Rothbaum and Groom (1961) that sulphur-superphosphate mixtures for aerial topdressing be limited to a content of $500 \mathrm{lb}$ of sulphur per ton of superphosphate. This recommendation, which varies according to the fineness of grinding of the sulphur, was made because of the risk of explosion in the hopper of the aeroplane of sulphur-superphosphate mixtures with higher sulphur contents.

In Table 1 the amounts of sulphur of different particle sizes which can be mixed with superphosphate are shown. Thus the finer the sulphur the smaller the quantity that can be used in mixtures.

\section{Field Trials}

Forms of Sulphur Trial at Moutere Station, alexandra

This trial was laid down on August 8, 1960, on an extremely sulphur-deficient Pigburn soil (brown grey earth). Lucerne which was used as the indicator plant was 
TABLE 1: QUANTITIES OF SULPHUR OF DIFFERENT PARTICLE SIZES THAT CAN BE MIXED WITH SUPERPHOSPHATE

Information Supplied by Physics and Enginecring Laboratory, D.S.I.R.

$\begin{array}{cc}\text { Sulphur Grade } & \text { Probab!e Safe Ouantity por Ton } \\ \text { of Mixture }\end{array}$

$* 100 \%-8+30$ BSS means $100 \%$ passed through an 8-mesh British Standard sieve but was retained on a 30-mesh BSS.

$\uparrow$ This is the grade being added to sulphur-superphosphate mixtures at present.

TABLE 2: FORMS OF SULPHUR TRIAL: MOUTERE STATION, ALEXANDRA, CENTRAL OTAGO

Production in lb D.M./Acre

\begin{tabular}{|c|c|c|c|c|c|}
\hline$\underset{1 b}{\text { Treatment }}$ & 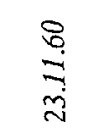 & $\begin{array}{l}\vec{b} \\
\stackrel{5}{ \pm}\end{array}$ & 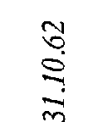 & \begin{tabular}{l}
3 \\
\hdashline \\
$i$
\end{tabular} & 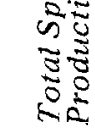 \\
\hline (1) Control .............. & 470 & 400 & 530 & 380 & $\overrightarrow{1,780}$ \\
\hline $\begin{array}{l}\text { (2) Coarse sulphur } 12 \% \\
\text { (3) Coarse sulphur } 25 \\
\text { (4) Coarse sulphur } 50\end{array}$ & $\begin{array}{l}760 \\
790 \\
820\end{array}$ & $\begin{array}{r}590 \\
710 \\
1,360\end{array}$ & $\begin{array}{r}900 \\
1,490 \\
2,840\end{array}$ & $\begin{array}{r}740 \\
1,030 \\
2,070\end{array}$ & $\begin{array}{l}2,990 \\
4,020 \\
7,090\end{array}$ \\
\hline 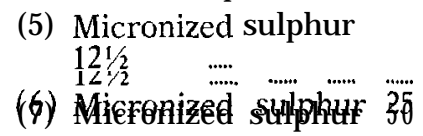 & $\begin{array}{r}790 \\
1,030 \\
1,410\end{array}$ & $\begin{array}{r}840 \\
1,440 \\
2,790\end{array}$ & $\begin{array}{c}890 \\
1,440 \\
3,510\end{array}$ & $\begin{array}{r}560 \\
980 \\
1,310\end{array}$ & $\begin{array}{l}3,080 \\
4,890 \\
9,020\end{array}$ \\
\hline 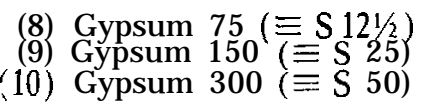 & $\begin{array}{r}3,250 \\
3,250 \\
3,270\end{array}$ & $\begin{array}{r}1,120 \\
2,160 \\
2,750\end{array}$ & $\begin{array}{r}1,710 \\
2,390 \\
4,470\end{array}$ & $\begin{array}{r}990 \\
1,090 \\
2,680\end{array}$ & $\begin{array}{r}7,070 \\
8,890 \\
13,170\end{array}$ \\
\hline
\end{tabular}

Coarse sulphur: $70.7 \%$ + 60 BSS; $120 \%$ - 60 BSS; $17.3 \%$ Micronized sulphur: $100 \%-100$ BSS.

Rainfall : September 1962-August 196319.30 in.

September 1963-August 19641467 in.

September 1964-August 196522.51 in.

100 BSS. 
established before the trial was laid down. In this experiment, three forms of sulphur are compared at three rates and a basal dressing of phosphate was applied. The treatments are shown in Table 2 and also the fineness of grinding of the sulphur treatments. The coarse sulphur used in this experiment was finer than the sulphur being added to superphosphate at the present time. The treatments were applied once only. The rainfall from September to August over the past three years is also given. In this trial, the lucerne is cut at the hay stage of growth and all the herbage is removed. The spring production for four seasons is given in Table 2 and also the total production for the four spring cuts.

In an adjacent four rates of phosphate $x$ four rates of elemental sulphur factorial trial, it was found that $50 \mathrm{lb}$ of elemental sulphur per acre was required to obtain maximum production from lucerne on this soil.

In the spring cut of 1960, 3\% months after the trial was laid down, very marked responses were obtained with gypsum at the rate of $75 \mathrm{lb}$ per acre. This result emphasizes the acuteness of the sulphur deficiency on this soil. Higher rates of gypsum were not superior at the time of this cut. The gypsum treatments were very much superior to the micronized sulphur treatments which were in turn superior at the higher rates to the coarse sulphur treatments. The marked responses obtained to the micronized sulphur treatments indicates that even under these low rainfall conditions at this site, oxidation of the elemental sulphur to sulphate took place in a short period of time.

The results for the cut in the spring of 1961 showed that at the optimum rate of $50 \mathrm{lb}$ of sulphur per acre, micronized sulphur was very much superior to coarse sulphur. Gypsum at the equivalent of $50 \mathrm{lb}$ of sulphur per acre was no better than micronized sulphur. In the spring of 1962, a similar result was obtained except that gypsum was markedly superior to micronized sulphur at the $50 \mathrm{lb}$ rate. In the spring cut in 1963, however, the coarse sulphur treatment at $50 \mathrm{lb}$ per acre was markedly superior to the micronized sulphur treatment. The gypsum was still markedly superior to the coarse sulphur treatment.

When the total spring production figures are studied for the $50 \mathrm{lb}$ of sulphur per acre rates, it is seen that micronized sulphur is superior to fine sulphur and gypsum is very much superior to micronized sulphur. Fineness of grinding has thus been shown to be an important factor in determining the rate at which sulphur is oxidized to sulphate. In 
two trials laid down on a sulphur responsive soil in the Rakaia Gorge, Walker ( 1957) and Walker and Adams (pers. comm.) have also reported the superiority of gypsum to sulphur at low rates but they found that at higher rates there was little difference between the two forms.

The tremendous residual effects of gypsum should be noted particularly at the rate of $300 \mathrm{lb}$ of gypsum per acre. These residual effects from gypsum are very much greater than the residual effects from coarse or fine sulphur. If the sulphur content of the lucerne is assumed to be $0.20 \%$ in the high rates of gypsum plots, then half of the original $50 \mathrm{lb}$ of sulphur per acre applied has been recovered in the spring cuts alone. Walker and Adams (1958) also reported the pronounced residual effects from gypsum applications and they suggested different ways in which the gypsum might be retained in the soil over the winter months.

This experiment was re-topdressed in the winter of 1964. Unfortunately, the spring of 1964 was very dry in Central Otago and it was not possible to take a production out. In the autumn of 1965, a cut was taken and the results are shown in Table 3. It can be seen that at the $50 \mathrm{lb}$ rate coarse sulphur is just as good as micronized sulphur. Gypsum, however, at the rate of $75 \mathrm{lb}$ per acre ( $12 \mathrm{l} / 2 \mathrm{lb}$ of sulphur) was as good as $50 \mathrm{lb}$ of micronized sulphur. It is suggested that the reason for the coarse sulphur at $50 \mathrm{lb}$ being equal to $50 \mathrm{lb}$ of micronized sulphur is that over the years the population of sulphur-oxidizing bacteria have built up in the coarse sulphur treatments.

TABLE 3: FORMS OF SULPHUR TRIAL: MOUTERE STATION, ALEXANDRA, CENTRAL OTAGO Production in $1 \mathrm{~b}$ D.M./Acre

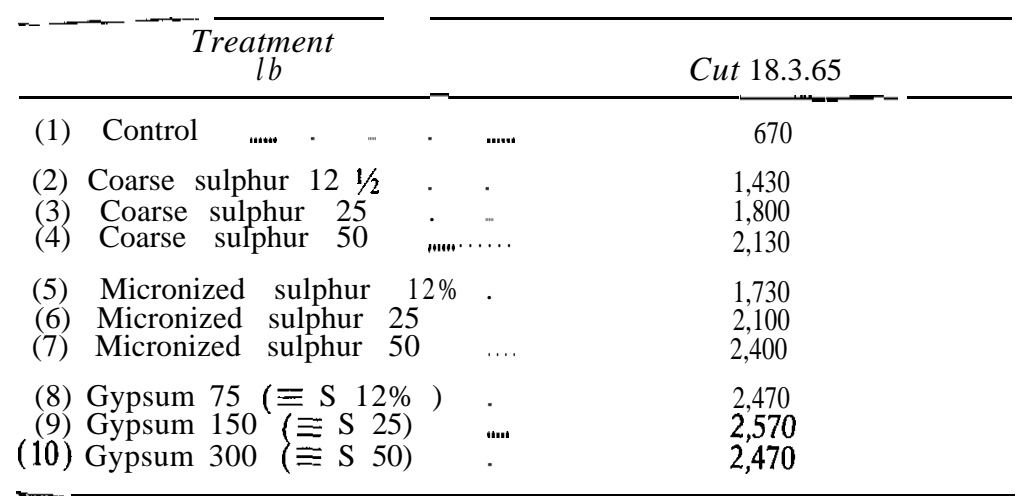


Forms of Sulphur Trial at Glencoe Station, Arrowtown

The experimental design in this experiment was identical to the trial at Moutere Station. The indicator plants were oversown clovers and the soil a Blackstone dry subhygrous yellow grey earth. The responses were measured by visual pointings. The natural vegetation at the site was a fescue tussock association. This experiment was laid down in September, 1962. In this experiment, very similar responses were obtained to those at Moutere Station. Micronized was superior to coarse sulphur at the $50 \mathrm{lb}$ rate and gypsum was superior to micronized sulphur. There were also marked residual responses to gypsum at the $300 \mathrm{lb}$ per acre rate.

Fineness of Grinding of Sulphur Trial at Glencoe Station, ARrowtown

This experiment which is adjacent to the Forms of Sulphur Trial was laid down in October, 1963. In this trial, elemental sulphur of six different particle sizes were compared with gypsum. The rate of sulphur in all treatments was $50 \mathrm{lb}$ per acre. The trial area received a' basal dressing of phosphate. The treatments are shown in Table 4. Products $A$ to $D$ were supplied by $A$. A. Duncan, Technical Adviser to the Dominion Fertilizer Company, Dunedin, and Product $\mathrm{E}$, which is micronized sulphur, was supplied by G. G. Taylor of Fruitgrowers Chemical Co. Ltd., Nelson. The fineness of grinding of the different grades of sulphur is given in Table 1 . The results of the visual pointings made in December, 1.964, and September, 1965, are shown in Table 4.

It is evident from these results, for the first two years of this trial, that the finer the sulphur the greater is the legume production. Products D, E and gypsum have given the same

TABLE 4: FINENESS OF GRINDING OF SULPHUR TRIAL:

GLENCOE STATION, ARROWTOWN, CENTRAL OTAGO VISUAL POINTINGS (FERTILITY INDEX)

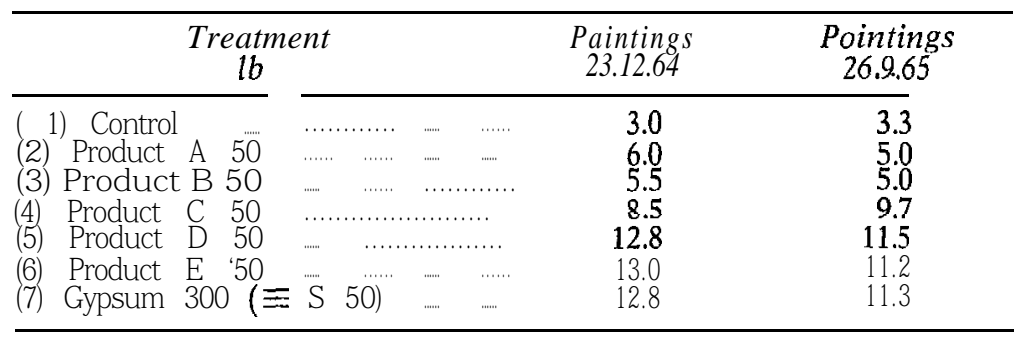


level of responses indicating that with very fine grinding the same benefits can be attained from sulphur as from gypsum. These results confirm the results of the Moutere trial that fineness of grinding is an important factor in determining the rate at which sulphur is oxidized to sulphate by micro-organisms.

Fineness OF Grinding of Sulphur Trial at Lindis Peaks Station, TARras

This trial is identical to the experiment at Glencoe Station. The indicator plant is lucerne and hence the responses are measured by taking production cuts. The trial was laid down in April, 1964, and the soil type is a Pigburn fine sandy loam (brown grey earth). The results of a production cut taken in the autumn 1965 are shown in Table 5. Owing to the very dry conditions, it was not possible to obtain a production cut in the spring of 1964.

TABLE 5: FINENESS OF GRINDING OF SULPHUR TRIAL, LINDIS PEAKS STATION, TARRAS, CENTRAL OTAGO Production in lb D.M./Acre

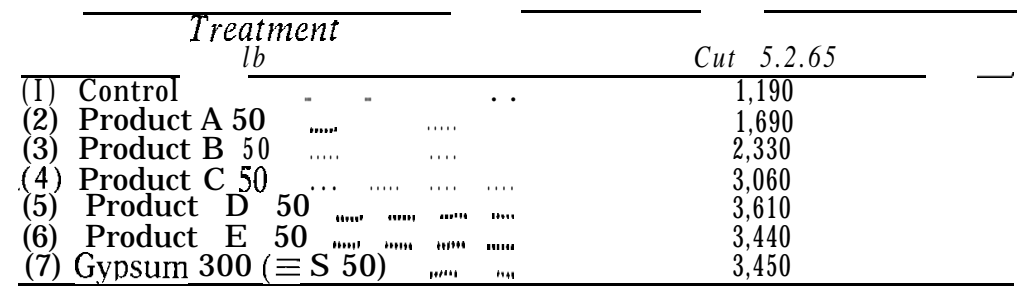

The responses are very similar to the responses obtained at Glencoe Station. In this trial, on lucerne, Product $C$ has given a greater response than at the trial at Arrowtown where clovers are the indicator plants.

The sulphur being added to superphosphate is coarser than product $C$ and just slightly finer than product $B$. Hence the efficiency being obtained from the sulphur in sulphurized superphosphate at the present time is low.

\section{Conclusions and Recommendations}

Gypsum has been shown to be a markedly superior form of sulphur to elemental in trials on these very sulphurresponsive soils in Central Otago. For topdressing these soils, investigations should be undertaken by government departments and farmer organizations into importing gypsum from South Australia. It is recommended that 
gypsum should be used on soils where sulphur is the only major nutrient limiting the growth of legumes. The soils which fall into this group are the majority of the brown grey earths and the dry subhygrous yellow grey earths that is, the majority of the soils in the valley floors and on the mountain ranges in Central Otago up to 2,000 ft.

Sulphurized superphosphate will be required on soils where there is a response to phosphate in the presence of sulphur (Ludecke, 196213). Fineness of grinding has been shown to be a very important factor in determining the rate at which elemental sulphur in sulphurized superphosphate is mineralized to sulphate. However, as was shown in Table 1 , the finer the sulphur the smaller the quantity that can be safely used in mixtures. The problem is to find the grade of sulphur which will give maximum responses within the limits of safety. It is the opinion of A. A. Duncan (pers. comm.) and the writer, after many investigations, that the optimum grade of sulphur that should be added to superphosphate is a grade where $40 \%$ passes a 60 mesh B.S.S. There are a number of technical problems associated with either further sieving or grinding of sulphur in fertilizer works, but it will be necessary' for these problems to be overcome to ensure that this finer grade of sulphur is added to superphosphate.

\section{A cknowledgements}

The writer wishes to acknowledge the assistance received in this work from A. A. Duncan, Technical Adviser to Dominion Fertilizer Co., Dunedin, and to thank also S. A. Grubb, Technician, Alexandra, for field work and G. G. Cossens, Field Research Officer, Alexandra, for collecting rainfall data at the Moutere Station site.

\section{REFERENCES}

Bruce-Smith, J. R. 1962: Movement of Sulphate Sulphur in Soils as Influenced by Certain Fertilizer Treatments. M.Agr.Sc. Thesis, Lincoln College Library.

Lobb, W. R.: Bennets, R. L., 1958: Improvement of tussock grassland in Canterbury. N.Z. J. A gric., 96: 537-49.

Ludecke, T. E., 1960: Improvement of low altitude tussock country in Central Otago. Proc. 22nd Con/. N.Z. Grassl. Ass., 96-110. 1962a: The Soil Chemistry of Some Central 0 tago Soils in Relution to the Pattern of Field Responses to Sulphur and Phosphorus. M.Agr.Sc. Thesis, Lincoln College Library.

1962b: Formulation of a rational fertilizer programme in

tussock country. Proc. 24th Conf. N.Z. Grassl. Ass., 29-41. 
McLeod, C. C., 1961: Good responses to sulphur in South Canterbury. N.Z.' J. Agric., 102: 225-36.

Rothbaum, H P.:Groom, P. S, 1961: A study of the problem of aerial topdressing of sulphur-delicicnt soils in $\mathrm{New}$ Zealand. N.Z. D.S.I.R. Dorn. Lab. Report, 2040.

Walker, T. W., 1957: Sulphur responses on pastures. Proc. 19th Conf. N.Z. Grassl. Ass., 117-24.

Walker, T. W.; Adams, A. F. R.: Orchiston, H. D., 1955: The effects and interactions of sulphur, phosphorus and molybdenum on growth and composition 01 clovers. N.Z. J. Sci. Tech. Sec. A. 36: $470-82$.

\section{DISCUSSION}

With reference to Table 2: (a) Why has $12 \% \mathrm{lb}$ of micronized sulphur not given a greater response than $12 \% \mathrm{lb}$ of coarse sulphur; and (b) Instead of using $300 \mathrm{lb}$ of gypsum, which is equivalent to $50 \mathrm{lb}$ of sulphur, could $3 \mathrm{cwt}$ of ordinary superphosphate be used?

(a) As is mentioned in the paper, in the first three seasons micronized sulphur was superior to coarse sulphur but in the fourth season coarse sulphur was superior to micronized sulphur. I consider that line sulphur is superior because there is a bigger surface area available for the micro-organisms to act upon.

(b) To apply $50 \mathrm{lb}$ of sulphur, $4 \mathrm{cwt}$ of ordinary superphosphate would be required. On most soils which are sulphur deficient only, there is no reason why 4cwt of superphosphate could not be used instead of $300 \mathrm{lb}$ of gypsum. It must be rcmcmbercd that on these soils the phosphate poition is only a carrier of the sulphate and is not required for legume growth. On some soils it may be a disadvantage to apply superphosphate as the phosphate ions will re place the sulphate ions on the anion exchange sites.

How does Mr Ludecke reconcile the superiority of gypsum as shown by his trials with other trials thut indicate that elemental sulphur as in superphosphate gives a longer term response?

I can find no records in the $\mathrm{New}$ Zealand literature where, in de tailed mowing or observational trials, the residual effects of ele mental sulphur have been shown to be superior to gypsum. Professor T. w. Walker and A. F. R. A dams of Lincoln College working in the Rakaia Gorge area also found the residual effects of gypsum to bc grcatcr than those from elemental sulphur.

(a) With reference to Table 2 , is this trial to be continued? (b) Would Mr Ludecke agree that it appears that under low rainfall, gypsum is superior, while elemental sulphur may be superior under high rainfall?

(a) Yes. The trial was retopdressed in the winter of 1964 and the results of a production cut taken in the autumn of 1965 are shown in Table 3.

(b) This may or may not be so. It certainly is not so below a 40-in rainfall zone and a great deal of the sulphur responsive tussock country experiences a rainfall less than this. It must be remembered that in high rainfall regions elemental sulphur will be used. On 
these soils, there will be a phosphate response as well as a sulphur response, hence sulphurized superphosphate will be used. Fineness of grinding of sulphur then becomes important.

\section{What is the response to molybdenum in Central 0 tago?}

In the last two years we have found that there are extensive areas of country which respond to molybdenum in the presence of sulphur alone. Then there are also the soils which respond to molybdenum in the presence of sulphur and phosphate. The soils which interest me are the ones which respond to sulphur and molybdenum and not phosphate. It is very usual to obtain a response to molybdenum without obtaining a response to phosphate.

\section{What effect does sulphur have on the tussock via the legumes?}

Once sulphur deficiencies have been rectified and there is vigorous clover growth, the growth and vigour of all the tussock grasses along with all other grasses increase tremendously.

At what price would it be uneconomic to bring gypsum into the country and apply it to the land?

I will answer this question by saying that it would be economic to apply gypsum to soils which respond only to sulphur, if the gypsum can be applied at a cost lower than applying superphosphate.

In the Turakina Valley, there is a deposit of gypsum. What would be the effect of spreading it on the adjacent farm land?

I am very interested to learn that there is a deposit of gypsum in $\mathrm{New}$ Zealand. It would be of little use applying to adjacent farm land unless one knew the soils were sulphur deficient. 